\title{
Antiproliferative, antioxidative and compounds identification from methanolic extract of passiflora foetida and its fractions
}

\begin{abstract}
Objective: Passiflora foetida is a species of passion flowers and known to have prominent medicinal plant with major phyto-constituents. It belongs to family Passifloraceae that has been widely used in traditional practice for asthma, nervous disorders and hypertensive. This study was conducted to determine the antiproliferative and antioxidant activities of Passiflora foetida leaves methanolic extract (PFME) against MCF-7, MDAMB-231, HeLa and Hep G2 cancer cell lines, as well as to determine the antiproliferative activity of the major fractions against HeLa cells, and evaluate the compounds present in the PFME and fractions.
\end{abstract}

Design: The methanolic extract of Passiflora foetida leaves and its fraction were screened for their antiproliferative activities, antioxidant activities and compounds present.

Materials and Methods:Antioxidant activity was evaluated using DPPH assay, FRAP assay, TPC assay and TFC assay. Antiproliferative activity towards MCF-7 (HTB22 $2^{\mathrm{TM}}$ ) and MDA-MB-231 (HTB-26 $\left.6^{\mathrm{TM}}\right)$ breast cancer cell lines, Hep G2 $\left(H B 8065^{\mathrm{TM}}\right)$ liver cancer cell line, HeLa $\left(\mathrm{CCL}-2^{\mathrm{TM}}\right)$ cervical cancer cell line and $\mathrm{L} 929\left(\mathrm{CCL}-1^{\mathrm{TM}}\right)$ normal cell line were observed and compared to tamoxifen as a positive control.

Results:Results indicated that the PFME exhibits a high antiproliferative activity against $\mathrm{HeLa}\left(\mathrm{IC}_{50}\right.$ of $\left.10.83 \pm 3.65 \mu \mathrm{g} / \mathrm{ml}\right)$. The PFME manifested high antiradical properties $\left(\mathrm{EC}_{50}\right.$ of $1.37 \pm 1.17 \mu \mathrm{g} / \mathrm{ml})$ and moderate antioxidant reducing power $(0.41 \pm 0.03 \mathrm{mM} \mathrm{FE})$, with $82.09 \pm 13.82 \mathrm{mg} \mathrm{GAE} / \mathrm{g}$ of TPC and $205.59 \pm 6.57 \mathrm{mg} \mathrm{QE} / \mathrm{g}$ of TFC values. However, fractions shows higher $\mathrm{IC}_{50}$ values against HeLa compared to PFME. GC-MS study revealed the presence 8-32 compounds from each sample. Tetradecanal was identified to possibly possess high anticancer properties.

Conclusion: This study is the first to demonstrate that PF has antiproliferative effect on human cervical cancer cells. PFME might be more potent than the fractions and demonstrates a moderate amount of antioxidant activity.

Keywords: antiproliferative, antioxidant, gc-ms, passiflora foetida, tetradecanal; hela
Volume 6 Issue I - 2017

\author{
Noor Nabilah Talik Sisin, Hasmah Abdullah, \\ Mohd Dasuki Sul'ain \\ 'Department of Biomedicine, University of Science Malaysia, \\ Malaysia \\ 2Department of Environmental \& Occupational Health, \\ University of Science Malaysia, Malaysia
}

Correspondence: Mohd Dasuki Sul'ain, Department of Biomedicine, School of Health Science, University of Science Malaysia, Health Campus, Kubang Kerian, 15200 Kubang Kerian, Kelantan, Malaysia, Tel 609767758I, Email drdasuki@usm.my

Received: July 23, 2017 | Published: September II, 2017
Abbreviations: PFME, passiflora foetida leaves methanolic extract; CCL, cancer cell line; CAM, complementary and alternative medicine; DMSO, dimethyl sulfoxide; $\mathrm{CO}_{2}$, carbon dioxide; $\mathrm{FE}$, ferrous equivalents; $\mathrm{Na}_{2} \mathrm{Co}_{3}$, sodium carbonate; GAE, gallic acid equivalent; QE, quercetin equivalents; ANOVA, analysis of variance; SD, standard deviation; DTBP, di-Tert-butylphenol

\section{Introduction}

Each year, approximately 8 million people died from cancers and half of them are in the age of 30 to 69 years old. ${ }^{1}$ Cancer cases, such as melanoma, prostate, liver, lung and breast cancers, are expected to increase per year in 2010 to $2020 .^{2}$ The estimated global population of 8.3 billion can be expected by 2025 , and thus increases the predicted new cancer cases of 20 million by the same year. ${ }^{3}$

Among the standard chemotherapeutic drugs that are currently being used in cancer treatments are tamoxifen, doxorubicin and cisplatin. Tamoxifen is an anti estrogen drug that is widely used in the treatment breast cancer and possibly can be used to treat liver and cervical cancers. ${ }^{4,5}$ Doxorubicin and cisplatin are also used to treat several types of cancer such as liver, bladder, lung, gastric, cervical, colon, and brain cancers. ${ }^{6}$
Treatments using complementary and alternative medicine (CAM) for cancer are only considered as the additional treatment, not yet as the standard treatments of cancers. ${ }^{7}$ Problems arose when chemotherapy caused several adverse effects such as low blood cell count, ototoxicity, peripheral neuropathy, menstrual irregularities, fertility disturbance and development of other type of cancer. ${ }^{6}$ The cancer patients are also gradually developing resistance to the standard chemotherapeutic drugs (Umthong et al. 2011). Thus, it is important to find new anticancer agents. The extracts derived from the natural plants are of interest as the new chemotherapeutic agent sources. ${ }^{8}$ Since attainment of data on phytochemicals and constituents of medicinal plants in treating and preventing diseases and cancers is significant, it is very important to discern and identify the active constituents in order to develop new natural-based drugs or medicine.

Passiflora foetidaplant was chosen based on its traditional uses for treatment of tumors. ${ }^{9}$ Extracts of $P$. foetida had been verified to have anticancer activities on in vivo and in vitro. ${ }^{10,11}$ The present study is a report of cytotoxic investigation of $P$. foetida extract and fractions against cervical cancer cell line (HeLa), and the compounds which are possibly responsible for the antiproliferative activity which led to identification of tetradecanal and cis-11-hexadecenal. 


\section{Materials and methods}

\section{Plant materials}

PF whole plant was collected from Kelantan, Malaysia. The taxonomic identity of the plant was authenticated by Dr. Shamsul Khamis and was deposited in Herbarium Kulliyyah of Pharmacy, International Islamic University Malaysia (Voucher specimen number PIIUM 0270).

\section{Extraction}

The collected PF leaves were rinsed, dried in incubator of $50^{\circ} \mathrm{C}$ for 3 to 4 days, and grind into powder. A fifty gram of PF dried leaves powder was soaked in $400 \mathrm{ml}$ methanol. It was left at room temperature (RT) overnight with occasional stirring. The mixture was filtered using filter paper $(240 \mathrm{~mm})$ into one container. The filtrate was concentrated by rotary vacuum evaporator and later was air-dried in fume hood for several days. It was referred as PF methanolic extract (PFME).

\section{Antiproliferative study}

Collection of cell lines from American Type Culture Collection (ATCC $\left(\right.$ ) ) were used; MCF-7 (HTB22 ${ }^{\mathrm{TM}}$ ) and MDA-MB-231 (HTB$\left.26^{\mathrm{TM}}\right)$ breast cancer cell lines, Hep G2 (HB $\left.8065^{\mathrm{TM}}\right)$ liver cancer cell line, HeLa (CCL-2 ${ }^{\mathrm{TM}}$ ) cervical cancer cell line and L929 (CCL-1 ${ }^{\mathrm{TM}}$ ) normal cell line. All the cells were maintained by routine passage every two to three days, except for MDA-MB-231 cells which needed to be wash every 24 hours to ensure it continuation to grow well and free from contamination. The method was conducted according to Zakariaet al. (2009) with slight modification. A culture flask with $80-90 \%$ cells confluence was chosen and the detached cells were seeded at $5 \times 10^{4}$ live cells $/ \mathrm{ml}$ in a $96-$ wells plate. When the cells reached $80-90 \%$ cells confluence, the old media was discarded. $200 \mu 1$ fresh culture media was added to each well. The PFMEand tamoxifen (positive control) were dissolved in DMSO to make $10 \mathrm{mg} / \mathrm{ml}$ stock solution. Two-fold serial dilutions were prepared for both PFME and tamoxifen, ranging from 0.39 to $100 \mu \mathrm{g} / \mathrm{ml}$. Each well received $2 \mu$ l of each concentration from the serial dilution. Negative control cultures received the same concentration of DMSO alone. The 96-well plate was incubated for 72 hours at $37^{\circ} \mathrm{C}$ incubator in a humidified atmosphere with $5 \% \mathrm{CO}_{2}$. At the end of the incubation period, the old media was discarded and $50 \mu \mathrm{l}$ of $2 \mathrm{mg} / \mathrm{ml}$ MTT solution was added to each well. The plate was then incubated again for 4 hours. Then, the MTT solution was replaced with $200 \mu \mathrm{L}$ DMSO. After 20 minutes, absorbance at $570 \mathrm{~nm}$ was read on a spectrophotometric plate reader. The proportion of surviving cells was/were calculated as ([absorbance of sample/ absorbance of control] x 100). Dose-response curves were constructed to obtain the $\mathrm{IC}_{50}$ values. All experimental data were derived from at least 3 independent experiments.

\section{Fractionation}

$10 \mathrm{~g}$ of PFME was taken up in 234g silica gel 70-230 mesh and run in a fritted $50 \mathrm{~cm} \times 40 \mathrm{~mm}$ column. The extract was eluted with petroleum ether: ethyl acetate (4:1). The type of petroleum ether used was petroleum ether with boiling range of $40-60^{\circ} \mathrm{C} .10 \mathrm{ml}$ to $15 \mathrm{ml}$ fractions were collected in test tubes and tested with thin layer chromatography. Fractions with similar spot patterns (same retention factor value) were combined and left to dry.

\section{Antioxidant studies}

DPPH assay:According to ${ }^{12}$ the assay was carried out in a 96 -well micro plate with a slight modification. The sample extract was diluted in methanol to prepared $100 \mu \mathrm{g} / \mathrm{ml}$ concentration of solution and followed by two-fold serial dilutions. The sample was added to freshly prepared $0.1 \mathrm{mM}$ DPPH solution with the ratio of $150 \mu \mathrm{l}$ of DPPH solution to $150 \mu 1$ sample and standard solutions and incubated in dark for 30min at RT. After incubation, the absorbance of the mixture was measured at $517 \mathrm{~nm}$ against methanol as blank. Gallic acid was used as a positive control, ${ }^{13}$ as it was found to have the highest antioxidant power and antiradical activity than other compounds. ${ }^{14}$ Then, scavenging activity (Q) will be calculated as $\left(\left[\mathrm{A}_{c}-\mathrm{A}_{\mathrm{s}}\right] / \mathrm{A}_{\mathrm{c}} \times 100\right) . \mathrm{A}_{\mathrm{c}}$ was the absorbance of control (DPPH solution without sample) at 517, and As was the absorbance at 517 of sample at different concentrations with DPPH. The antioxidant activity was expressed as $\mathrm{EC}_{50}(\mu \mathrm{g} / \mathrm{ml})$, the concentrations of the sample required to cause a $50 \%$ decrease of the absorbance at $517 \mathrm{~nm}$. All samples were analyzed in triplicates.

FRAP assay: The method follows closely that used by ${ }^{13}$ with slight modification. $20 \mu \mathrm{L}$ of $1000 \mu \mathrm{g} / \mathrm{ml}$ extract in methanol was mixed with $180 \mu \mathrm{L}$ FRAP reagent in wells of a 96-well plate. The plate was incubated for 6 minutes, and the absorbance was measured at $593 \mathrm{~nm}$. FRAP reagent was prepared according to García-Carrasco et al. ${ }^{15}$ Blanks of sample and solvent only were run together with gallic acid (in $\mathrm{MeOH}$ ) as a positive control. Iron (III) sulphate $\left(\mathrm{FeSO}_{4}\right)$ was used as a standard and the concentrations to make a standard curve were 0.1-1.0mM. FRAP activity was calculated as mM Ferrous Equivalents (FE), the concentration of extract/gallic acid which produced an absorbance value equal to that of $1 \mathrm{mM} \mathrm{FeSO}_{4}$. All samples were analyzed in triplicates.

TPC assay: According to Herald et al. ${ }^{16}$ the TPC assay was carried out in a 96-well microplate with a slight modification. To develop a standard calibration curve, $75 \mu$ distilled water, $25 \mu 1$ of gallic acid solutions $(0.49$ to $250 \mu \mathrm{g} / \mathrm{ml})$, and $25 \mu \mathrm{l}$ of Folin-Ciocalteu reagent (diluted 1:1 (v/v) with $\mathrm{dH} 2 \mathrm{O})$ were mixed together and left for 6 minutes. After that, $100 \mu \mathrm{l}$ of $75 \mathrm{~g} / 1$ sodium carbonate $\left(\mathrm{Na}_{2} \mathrm{CO}_{3}\right)$ solution was added and left in dark for 90 minutes. $1000 \mu \mathrm{g} / \mathrm{ml}$ extract was oxidized with Folin-Ciocalteu reagent and neutralized by $\mathrm{Na}_{2} \mathrm{CO}_{3}$ solution as given for the standard. The absorbance of solution was recorded at $650 \mathrm{~nm}^{17}$ against methanol as blank (set to shake for $60 \mathrm{~s}$ before reading). TPC was expressed as $\mathrm{mg}$ of gallic acid equivalent (GAE)/g of dry plant material weight (dw). All samples were analyzed in triplicates.

TFC assay: The method follows closely that used by Chatatikun et al. ${ }^{18}$ with slight modification. Briefly, $50 \mu 1$ of $1 \mathrm{mg} / \mathrm{ml}$ extract or standard solution of quercetin $(6.25$ to $100 \mu \mathrm{g} / \mathrm{ml})$ in $80 \%$ ethanol was added to $10 \mu 1$ of aluminium chloride $(0.1 \mathrm{~g} / \mathrm{ml})$ solution and followed by $150 \mu 1$ of $95 \%$ ethanol. $10 \mu \mathrm{l}$ of sodium acetate $(83.03 \mathrm{~g} / \mathrm{l})$ was added to the mixture in a 96 wells plate. $80 \%$ ethanol was used as the blank. All mixture were shaken and incubated at RT in dark for 40 minutes. The absorbance was measured at $415 \mathrm{~nm}$. TFC was expressed as $\mathrm{mg}$ quercetin equivalents $(\mathrm{QE}) / \mathrm{g} \mathrm{dw}$. All samples were analyzed in triplicates.

\section{Compounds screening using gas chromatography- mass spectrometry}

GC-MS analysis was performed on a GC/MS Perkin Elmer Clarus $^{\mathrm{TM}}$ SQ8 fitted with an Elite-5MS capillary column $(30 \mathrm{~m}$ $\mathrm{L} \times 0.25 \mathrm{~mm}$ I.D. $\times 0.25 \mu \mathrm{m}$ film thickness). Purified helium (99.999\%) was used as carrier gas at a constant flow of $1 \mathrm{ml} / \mathrm{min}$. All data were obtained by collecting the full-scan mass spectra within the scan range of $40-500 \mathrm{~m} / \mathrm{z}$. The sample was prepared in dichloromethane, and the injected sample volume was $1.0 \mu 1$ with a split ratio of $60: 1$. The 
oven temperature program was $50^{\circ} \mathrm{C}$ and accelerated to $120^{\circ} \mathrm{C}$ at a rate of $10^{\circ} \mathrm{C} /$ minute, up to $280^{\circ} \mathrm{C}$ a rate of $5^{\circ} \mathrm{C} /$ minute. The unknown compounds were identified by comparing the spectra obtained with National Institute Standard and Technology Mass Spectral Library.

\section{Statistical analysis}

All statistical analysis was performed using Microsoft Excel and GraphPad PRISM. Each experiment was carried out in triplicate and the results were presented as mean values \pm standard deviation (SD) of three independent experiments. The statistical significance of data of the assays obtained were calculated using Student's t-test, one-way analysis of variance (ANOVA) with Dunnet's multiple comparison test, and Pearson's correlation test.

\section{Results and discussion}

\section{Antiproliferative studies of PFME and fractions on selected cancer cell lines}

The $\mathrm{IC}_{50}$ values of PFME were more than $100 \mu \mathrm{g} / \mathrm{ml}$ for all the cancer cell lines except for cervical cancer cell line, HeLa. The PFME exhibits a promising anti proliferative activity against $\mathrm{HeLa}$ with $\mathrm{IC}_{50}$ value $10.83 \pm 3.65 \mu \mathrm{g} / \mathrm{ml}$ (Figure 1)

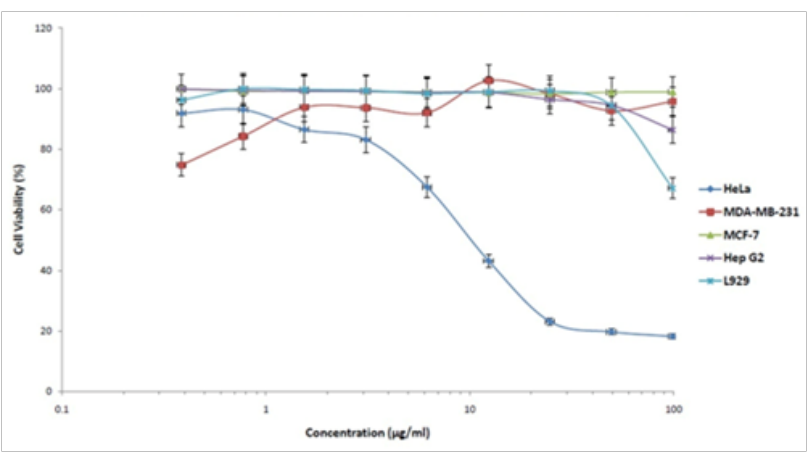

Figure I Antiproliferative activity of PFME against 5 different cell lines by MTT assays.

The cell lines are HeLa (cervical), MDA-MB-23I and MCF-7 (breast), Hep G2 (liver) and L929 (normal) cell lines. Each point shows the percentage of viable cells compared to negative control, DMSO.

According to NCI, samples with $\mathrm{IC}_{50}$ value less than $30 \mu \mathrm{g} / \mathrm{ml}$ on cancer cell lines could be considered as prospective candidates of new anticancer agents ${ }^{19}$ and might contain active compounds with anticancer properties. ${ }^{8}$ Results of the current study were potent enough and fit the characters. Biostatiscally, the mean difference of $\mathrm{IC}_{50}$ values between PFME and positive control drug, tamoxifen, on HeLa is not statistically significant $(\mathrm{p}>0.05)$ (Table 1$)$.

Table I The $\mathrm{IC}_{50}$ values of PFME and tamoxifen against cancer and norma cell lines

\begin{tabular}{|c|c|c|c|}
\hline \multirow{2}{*}{ Cell Lines } & & \multicolumn{2}{|c|}{$I C_{50}(\mu \mathrm{g} / \mathrm{ml})$} \\
\hline & & PFME & Tamoxifen \\
\hline \multirow{4}{*}{ Cancer cells } & HeLa (Cervix) & $10.83 \pm 3.65$ & $3.08 \pm 0.58$ \\
\hline & MDA-MB-23I (Breast) & $>100$ & $4.00 \pm 0.79$ \\
\hline & MCF-7 (Breast) & $>100$ & $6.42 \pm 1.78$ \\
\hline & Hep G2 (Liver) & $>100$ & $3.95 \pm 0.28$ \\
\hline Normal cells & L929 & $>100$ & $4.00 \pm 0.35$ \\
\hline
\end{tabular}

The values are represented as mean \pm SD.

This may suggest that PFME is as effective as positive control drug on cervical cancer cells. Furthermore, PFME showed low inhibition effects against L929 normal cells, and MDA-MB-231, MCF-7 as well as Hep G2 cancer cells with $\mathrm{IC}_{50}$ values of more than $100 \mu \mathrm{g} / \mathrm{ml}$. If the $\mathrm{IC}_{50}$ values of samples were more than $100 \mu \mathrm{g} / \mathrm{ml}$, it was considered as exhibiting no cytotoxic ability. ${ }^{8,20}$ Poor cytotoxic activity of sample against normal cells signified its good selective antiproliferative activity (Umthong et al. 2011) and it might have properties that could differentiate the phenotypes between normal and cancerous cells. ${ }^{21}$ Thus, PFME is considered as cytoselective on cervical cancer cell line.

Since PFME gave the lowest $\mathrm{IC}_{50}$ value on HeLa cell line, thus this cell line was used in the subsequent experiments, for the treatment using the fractions. Table 2 listed the $\mathrm{IC}_{50}$ values of $\mathrm{F} 1$ to $\mathrm{F} 5$ fractions against $\mathrm{HeLa}$ cell line. All fractions showed $\mathrm{IC}_{50}$ values of more than $30 \mu \mathrm{g} / \mathrm{ml}$. Among the five fractions obtained, $\mathrm{F} 5$ gave the lowest $\mathrm{IC}_{50}$ value. Even though the value was higher than the NCI reference value, plant extracts with $\mathrm{IC}_{50}$ values within range of 30 to $200 \mu \mathrm{g} /$ $\mathrm{ml}$ have the potential to be refined into anticancer agents ${ }^{19,22}$ Based on the overall evaluations of antiproliferative activities among PFME and its fractions, the $\mathrm{IC}_{50}$ value of $\mathrm{F} 5$ was higher than the PFME. The findings suggested that the PFME was more potent than the fractions. It is possible that combinations of several compounds from different fractions might generate synergistic effect on antiproliferative activity. ${ }^{23}$

Table 2 The $\mathrm{IC}_{50}$ values of tamoxifen and five fractions against the HeLa cell line

\begin{tabular}{lll}
\hline Positive Control and Fractions & & $\mathrm{IC}_{50}(\mathbf{\mu g} / \mathbf{m l})$ \\
\hline Tamoxifen & & $\mathbf{2 . 9 0} \pm \mathbf{0 . 2 I}$ \\
\hline & $\mathrm{FI}$ & $>100.0$ \\
PFME Fractions & $\mathrm{F}^{*}$ & $65.67 \pm 2.08$ \\
& $\mathrm{~F}^{*}$ & $80.00 \pm 5.20$ \\
& $\mathrm{~F} 4^{*}$ & $66.50 \pm 3.04$ \\
& $\mathrm{~F} 5^{*}$ & $47.83 \pm 7.59$ \\
\hline
\end{tabular}

The values are represented as mean \pm SD. $*$ Mean difference was significant $(p$ $<0.05)$ against positive control, tamoxifen.

\section{Antioxidant studies of passiflora foetida methanolic extract (PFME)}

Since PFME was found to be more potent in antiproliferation of cancer cells, only PFME was tested for its antioxidant activity. The estimated $\mathrm{EC}_{50}$ value of PFME was $1.37 \pm 1.17 \mu \mathrm{g} / \mathrm{ml}$, which was higher than the positive control gallic acid (Table 3). High free radical scavenging activity of a sample was indicated by its low $\mathrm{EC}_{50}$ value. ${ }^{24,25}$ The present finding may suggest that PFME have high antiradical abilities. This hypothesis is in line with other previous studies. The extract might be have active antioxidant compounds if its $\mathrm{EC}_{50}$ value was less than $4000 \mu \mathrm{g} / \mathrm{ml},{ }^{17}$ and it might has extremely high antiradical activity if its $\mathrm{EC}_{50}$ value was less than $10 \mu \mathrm{g} / \mathrm{ml} .^{26}$

Table 3 Antioxidant activity of PFME determined by DPPH, FRAP, TPC and TFC methods

\begin{tabular}{lllll}
\hline & DPPH & FRAP & TPC & TFC \\
\hline & EC $_{50}(\boldsymbol{\mu g} / \mathbf{m l})$ & (mM FE) & (mg GAE/g) & (mg QE/g) \\
\hline PFME & $1.37 \pm 1.17$ & $0.41 \pm 0.03^{\mathrm{a}, \mathrm{b}}$ & $82.09 \pm 13.82^{\mathrm{a}}$ & $205.59 \pm 6.57^{\mathrm{a}}$ \\
Gallic acid & $<0.39$ & $2.26 \pm 0.04$ & - & - \\
\hline
\end{tabular}

Experiments were performed in triplicate and expressed as mean $\pm S D$. ${ }^{\text {a }}$ Concentration used was $1000 \mu \mathrm{g} / \mathrm{ml}$. ${ }^{b}$ The mean difference was significant ( $p<$ 0.05) against positive control, gallic acid.

The DPPH radical scavenging activity of PFME was also expressed to have positive correlation with FRAP results $(\mathrm{R}=0.957)$. FRAP assay 
demonstrated that PFME contained moderate amount of antioxidative compounds $(0.41 \pm 0.03 \mathrm{mM} \mathrm{FE})$. However, in comparison to the positive control gallic acid, the PFME was significantly less active, biostatistically. Extracts with high antioxidative activity have FRAP value approximately more than $0.9 \mathrm{mM}$, while extracts with low antioxidative activity have FRAP value approximately less than $0.011 \mathrm{mM} .{ }^{27}$ Thus, gallic acid was confirmed to be highly antioxidative, and PFME was only moderately antioxidative.

Furthermore, in TPC assay, a linear calibration curve of gallic acid with GAE equation $y=0.005 x+0.083\left(r^{2}=0.996\right)$ was obtained. The presence of phenols in PFME was measured up to $82.09 \pm 13.82 \mathrm{mg}$ GAE/g. Extracts with TPC value of more than $20 \mathrm{mg}$ GAE/ g was considered as a high value. ${ }^{28}$ This hypothesis contradicts with another study ${ }^{12}$ who coordinated range groups of TPC values. High TPC of samples should be within the values of more than $400 \mathrm{mg} \mathrm{GAE} / \mathrm{g}$, while moderate TPC group is within the values of $150-400 \mathrm{mg} \mathrm{GAE} / \mathrm{g}$. However, PFME fell into the last group; the low TPC with value of less than $150 \mathrm{mg} \mathrm{GAE} / \mathrm{g}$. Similarly, the current finding was supported by another two studies ${ }^{29,30}$ that found low amount of TPC in PF leaves.

The TPF value was also demostrated to have positive correlation with TFC $(\mathrm{R}=0.783)$. The TFC of PFME quantified was $205.59 \pm 6.57 \mathrm{mg} Q E / g$, using QE equation $\mathrm{y}=0.000374 \mathrm{x}+0.024\left(\mathrm{r}^{2}\right.$ $=0.999)$. The present study demonstrated that PFME had moderate TFC. Extracts with moderate TFC exhibited values within the range of $100-800 \mathrm{mg} \mathrm{QE} / \mathrm{g} .{ }^{31}$ However, the current findings contradicts to a study ${ }^{30}$ which found that the TFC of the PF leaves extract was low. This may be due to the difference of solvent and extraction methods used for extraction.

Many studies have proven that extracts with antioxidant effects were also reported to have anticancer properties..$^{29,32-35}$ This statement is in agreement with the current findings. Antioxidant could protect the normal cells from DNA damage and restrain cancer cells development ${ }^{36}$ and might cause antiproliferation of cancer cells by affecting antioxidant enzymes ${ }^{37}$ and apoptosis in the cancer cells. ${ }^{32}$

\section{Compounds screening using GC-MS}

From the GC-MS analysis, a total of 8 compounds were identified in PFME, 16 compounds were identified in each F1 and F2, 18 compounds were identified in F3, 25 compounds were identified in F4, and 31 compounds were identified in F5. These compounds were resolved at concentrations ranging from 0.19 to 48.83 per cent, and retention time ranging from 13.56 to 39.92 minutes. Primarily, discussions will be focussed on the eight compounds detected from PFME and their association to compounds identified in F1 to F5 fractions (Table 4).

Biologically important compounds that were determined from PFME were cis-11-hexadecenal (48.20\%), tetradecanal (17.69\%), phytol acetate $(14.04 \%), 3, \quad 5$-di-tert-butylphenol $(5.95 \%)$, 5 -octadecenal (5.85), ethyl iso-allocholate (3.38\%), 10-octadecenal $(2.63 \%)$, and eicosatrienoic acid methyl ester (2.25\%) (Figure 2).Nonetheless, no previous data had recorded the anticancer activity of extracts that contained cis-11-hexadecenal and 10-octadecenal. Although cis-11-hexadecenal is the most abundant compound in PFME and F4, there were scarce reports on the bioactivity of the compounds, except its associations as an antidiabetic component from $P$. foetidaplant ${ }^{39}$ and an insect sex pheromones agent. ${ }^{39}$ Besides, the only bioactivity of extracts with 10-octadecenal reported was antibacterials. ${ }^{40}$ Hence, this present study is the first to address the possible relationship between cis-11-hexadecenal and 10-octadecenal with the in vitro antiproliferative effect on $\mathrm{HeLa}$ cancer cells, which might occurred in synergism as the effect of PFME or buffering effect as of F4 with other compounds.<smiles>CCCCCCCCCCCCCC=O</smiles>

Tetradecenal.<smiles>CCCC/C=C/CCCCCCCCCC=O</smiles>

Cis-11-Hexadecenal<smiles>CC(=O)OC/C=C(\C)CCCC(C)(C)CCCC(C)(C)CCCC(C)O</smiles>

Phytol acetate.<smiles>CC(C)(C)c1cc(O)cc(C(C)(C)C)c1</smiles>

3,5-Di-tert-butylphenol.<smiles>CCCCCCCCCCCC/C=C/CCCC=O</smiles>

5-Octadecenal.

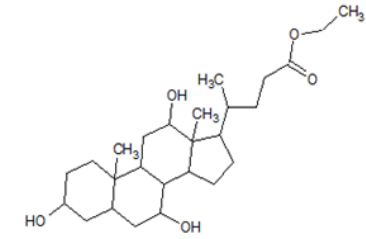

Ethyl iso-allocholate.

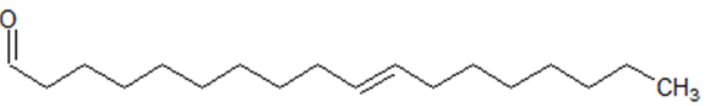

10-Octadecenal.

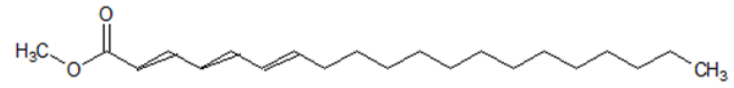

Eicosatrienoic acid methyl ester.

Figure 2 Chemical structure of anticancer compounds in PFME.

Second major compound identified in PFME was tetradecanal. Previously, this aldehyde compound was discovered in fractions of Sarcopoterium spinosum.$^{41}$ In agreement to the present study that testified the antiproliferative effect of PFME on HeLa cell line, the fractions of $S$. spinosum was found to have $\mathrm{IC}_{50}$ value of $32.1 \mu \mathrm{g} / \mathrm{ml}$ against HeLa cell line. ${ }^{41}$ As tetradecanal was present in PFME and 
absent in all fractions, it might justify that tetradecanal could have high potential antiproliferative effect on HeLa cells.

Additionally, phytol acetate is the third major compound in PFME. A previous report on Dicranumscopariumproposed that fractions of the plant contained phytol acetate and proffered antiproliferative effects on HeLa cancer cells. ${ }^{42}$ Since phytol acetate was also present in F1, F3 and F4, the findings might indicate that phytol acetate did not have high impact on antiproliferation of cancer cells.

Table 4 Comparative GC-MS analysis of compounds in PFME and fractions (FI to F5). 8 to 32 compounds were identified in the PFME and the fractions. Overall, a total of 88 compounds detected in GC-MS spectra of the six samples

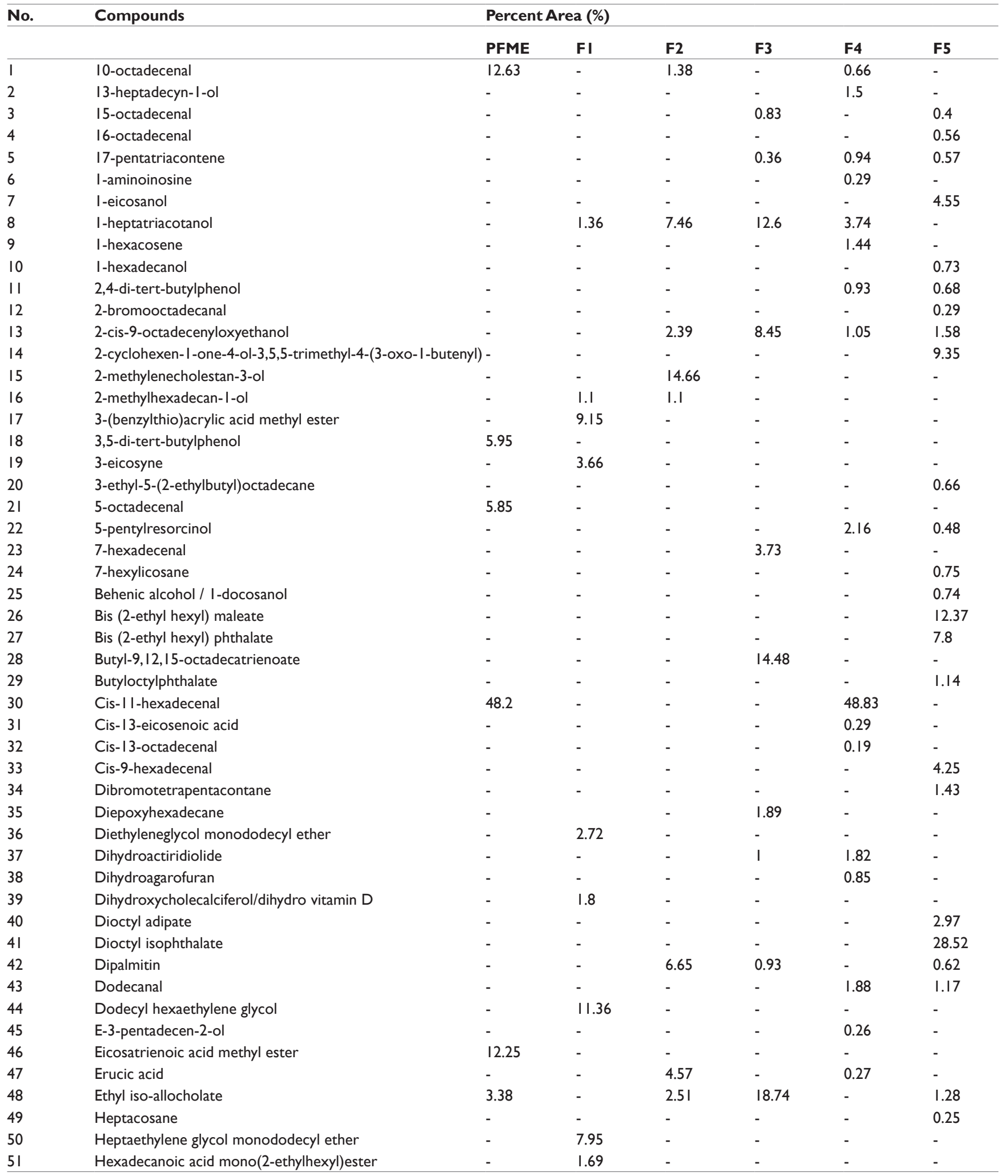


Table Continued..

\begin{tabular}{|c|c|c|c|c|c|c|c|}
\hline \multirow[t]{2}{*}{ No. } & \multirow[t]{2}{*}{ Compounds } & \multicolumn{6}{|c|}{ Percent Area (\%) } \\
\hline & & PFME & $\mathbf{F I}$ & $\mathbf{F 2}$ & $\mathbf{F 3}$ & F4 & $\mathbf{F 5}$ \\
\hline 52 & Hexadecenal & - & - & - & - & 17.85 & 4.78 \\
\hline 53 & Hexadecyl trichloroacetate & - & - & - & - & & \\
\hline 54 & Hexahydro farnesyl acetone & - & - & 26.94 & 11.76 & 4.07 & 2.32 \\
\hline 55 & Isophytol & - & - & 1.07 & - & - & - \\
\hline 56 & Lauryl triethoxylate & - & 8.98 & - & - & - & - \\
\hline 57 & Linoleic acid athyl ester & - & - & - & - & 0.51 & - \\
\hline 58 & Linoleoyl chloride & - & - & - & - & 0.64 & - \\
\hline 59 & Methyl hexadecanoate/ Hexadecanoic acid methyl ester & - & 6.99 & 3.85 & - & - & 3.16 \\
\hline 60 & Methyl-8-tetradecenyl acetate & - & - & - & 10.42 & - & - \\
\hline 61 & Nonadecatriene-5, |4-diol & - & - & - & - & 2.67 & - \\
\hline 62 & Octadecadienoic acid methyl ester & - & - & 2.53 & - & - & - \\
\hline 63 & Octadecanal & - & - & 1.39 & 0.41 & - & - \\
\hline 64 & Octaethylene glycol monododecyl ether & - & 13.76 & - & - & - & - \\
\hline 65 & Octatriacontyl pentafluoropropionate & - & - & - & - & 0.71 & - \\
\hline 66 & Phytol & - & - & 9.71 & 3.14 & - & - \\
\hline 67 & Phytol acetate & 14.04 & $|1.4|$ & & 2.81 & 5.25 & - \\
\hline 68 & P-methan-I-ol & - & - & - & - & 0.19 & - \\
\hline 69 & Sacreroside & - & 3.3 & - & - & - & - \\
\hline 70 & Tert-hexadecanethanol & - & - & 5.77 & - & - & - \\
\hline 7I & Tert-hexadecanethiol & - & - & - & - & - & 3.47 \\
\hline 72 & Tertramethyl-2-hexadecene-I-ol & - & 2.76 & 9.4 & 8.19 & - & - \\
\hline 73 & Tetradecanal & 17.69 & - & - & - & - & - \\
\hline 74 & Tetradecyl trichloroacetate & - & - & - & - & - & 1.83 \\
\hline 75 & Tetratetracontane & - & - & - & - & - & 0.27 \\
\hline 76 & Trimethyltetradecane & - & - & - & - & - & 1.03 \\
\hline 77 & $\alpha$-glyceryl linolenate & - & - & - & 10.42 & - & - \\
\hline 78 & $\gamma$-palmitolactone & - & 7.05 & - & - & - & - \\
\hline
\end{tabular}

Another biologically important compound in PFME was 3,5-ditert-butylphenol (3,5-DTBP), a phenol derivative. The extract containing 3,5-DTBP was proclaimed to cause DNA damage and cytotoxicity towards Hep G2 cancer cell line ${ }^{43}$ ). Its isomer 2,4-ditert-butylphenol (2,4-DTBP) was identified in F4 and F5 fractions. Isomerization is one of the major decomposition processes that could occur during fractionation. ${ }^{44}$ The 2,4-DTBP was found in a fraction of Pereskia bleo leaves. The extract possessed very remarkable cytotoxic activity against MCF-7 with $\mathrm{IC}_{50}$ value of $5.75 \mu \mathrm{g} / \mathrm{ml} .^{45}$ However, PFME was not cytotoxic on Hep G2 and MCF-7 as reported by the above studies. Thus, it is assumed that both phenol derivatives are not critical in anticancer process.

Meanwhile, ethyl iso-allocholate was detected in PFME as well as F2, F3 and F5. The extracts of other plants that comprised ethyl isoallocholate compound have also showed antiproliferative activities against MCF-7 and Hep G2 with $\mathrm{IC}_{50}$ values within the range of 31.08 to $78.89 \mu \mathrm{g} / \mathrm{ml} .^{34,46,47}$ The current data contradicts to the mentioned studies as PFME showed no antiproliferative effects on MCF-7 and Hep G2 cancer cells. Additionally, ethyl iso-allocholate was the most abundant compound in F3, yet it caused low cytotoxicity against HeLa cells. This situation may denote that ethyl iso-allocholate not selective towards MCF and Hep G2 cells and could cause buffering effects.

Lastly, eicosatrienoic acid methyl ester had also been identified in PFME. This compound had also been detected in a fraction of Echeveria subrigida plant, with $97.6 \%$ inhibition of mutagen1-NP on Salmonellatyphimurium YG1024 using Kado microsuspension assay. ${ }^{48}$ Gene mutation caused development of cancer, ${ }^{26}$ thus antimutagen could be considered as anticancer. Therefore, eicosatrienoic acid methyl ester might have potential compounds could be a candidate of anticancer agents.
In relation to the antioxidant study of PFME, there is no record on antioxidant activity of cis-11-hexadecenal. The moderate antioxidant activity of PFME might be the attributes of the minor compounds; 3,5 -DTBP ${ }^{49}$ eicosatrienoic acid methyl ester, ${ }^{50}$ ethyl iso-allocholate, ${ }^{34}$ phytol acetate, ${ }^{51}$ and tetradecanal. ${ }^{52}$

\section{Conclusion}

In conclusion, PFME exhibit more potent antiproliferative activity compare to fractions. The PF extract demonstrated a high antiproliferative effect on human cervical cancer cells. The effect could be contributed by tetradecanal compound. Cis-11-hexadecenal and 10-octadecenal could also have the potential to cause in vitro antiproliferative effect towards cervical cancer cells. Individual or combinations of several compounds might have synergistic or buffering effects on antiproliferative and antioxidant activities.

\section{Acknowledgements}

The authors are grateful to Kulliyyah of Pharmacy and Kuliyyah of Science, International Islamic University Malaysia for providing necessary facilities (herbarium and GC-MS services) to carry out this work successfully.

\section{Conflicts of Interset}

None.

\section{References}

1. http://www.worldcancerday.org/about

2. http://www.cdc.gov/cancer/cervical/basic_info/diagnosis_treatment. htm 
3. http://www.who.int/ionizing radiation/research/iarc/en/

4. https://clinicaltrials.gov/ct2/show/results/NCT00003424

5. Majumdar SK, Valdellon JA, Brown KA. In vitro Investigations on the Toxicity and Cell Death Induced by Tamoxifen on Two Non-breast Cancer Cell Types. J Biomed Biotechnol. 2001;1(3):99-107.

6. http://chemocare.com/chemotherapy/drug-info/

7. http://www.cdc.gov/cancer/dcpc/research/articles/cancer_2020.htm

8. Ampasavate C, Okonogi S, Anuchapreeda S. Cytotoxicity of Extracts From Fruit Plants Against Leukemic Cell Lines. African J Pharm Pharmacol. 2010;4(1):13-21.

9. Lim TK. Passiflora foetida. (4th edn), Edible Medicinal And NonMedicinal Plants, Springer Science \& Business Media, Germany, 2012. p. 166-173.

10. Arung ET, Kusuma IW, Christy EO, et al. Evaluation of Medicinal Plants from Central Kalimantan for Antimelanogenesis. J Nat Med. 2009;63(4):473-480.

11. Balasubramaniam A, Manivannan R, Baby E. Anticarcinogenic Effect of Passiflora foetida Linn Root on the Development of Liver Cancer Induced by DEN in Rats. Int J Drug Formul Res. 2010;1(2):144-151.

12. Jing L, Ma H, Fan P, et al. Antioxidant Potential, Total Phenolic an Total Flavonoid Contents of Rhododendron anthopogonoides and Its Protective Effect on Hypoxia-induced Injury in PC12 Cells. BMC Complementary and Alternative Medicine. 2015;15(1):287.

13. Lu Y, Knoo T-J, Wiart C. Phytochemical Analysis and Antioxidant Activity Determination on Crude Extracts of Melodinus eugeniifolus Barks and Leaves from Malaysia. Pharmacol Pharm. 2014;5(8):773780 .

14. Brand-Williams, Cuvelier ME, Berset C. Use of a Free Radical Method to Evaluate Antioxidant Activity. LWT - Food Sci Technol. $2015 ; 28(1): 25-30$.

15. García-Carrasco B, Fernandez-Dacosta R, Dávalos A, et al. In vitro Hypolipidemic and Antioxidant Effects of Leaf and Root Extracts of Taraxacum Officinale. Med Sci. 2015;3(2):38-54.

16. Herald TJ, Gadgil P, Tilley M. High-throughput Micro Plate Assays for Screening Flavonoid Content and DPPH-scavenging Activity in Sorghum Bran and Flour. J Sci Food Agric. 2012;92(11):2326-2331.

17. Clarke G, Ting KN, Wiart C, et al. High Correlation of 2,2-diphenyl-1picrylhydrazyl (DPPH) Radical Scavenging, Ferric Reducing Activity Potential and Total Phenolics Content Indicates Redundancy in Use of All Three Assays to Screen for Antioxidant Activity of Extracts of Plants from Malaysian Rainforest. Antioxidants (Basel). 2013;2(1):1-10.

18. Chatatikun M, Chiabchalard A. Phytochemical Screening and Free Radical Scavenging Activities of Orange Baby Carrot and Carrot (Daucus carota Linn.) Root Crude Extracts. J Chem Pharm Res. 2016;5(4):97-102.

19. Gulati V, Gulati P, Harding IH, et al. Exploring the Anti-diabetic Potential of Australian Aboriginal and Indian Ayurvedic Plant Extracts using Cellbased Assays. BMC Complement Altern Med. 2015;15(8):1-11.

20. Okonogi S, Duangrat C, Anuchpreeda S, et al. Comparison of Antioxidant Capacities and Cytotoxicities of Certain Fruit Peels. Food Chemistry. 2015;103(3):839-846.

21. Kahnberg P, Lucke AJ, Glenn MP, et al. Design, Synthesis, Potency, and Cytoselectivity of Anticancer Agents Derived by Parallel Synthesis from a-Aminosuberic Acid. J Med Chem. 2016;49(26):7611-7622.

22. Baharara J, Amini E, Namvar F. Evaluation of the Anti-proliferative Effects of Ophiocoma erinaceus Methanol Extract Against Human Cervical Cancer Cells. Avicenna J Med Biotechnol. 2016;8(1):29-35.
23. Awouafack MD, Mcgaw LJ, Gottfried S, et al. Antimicrobial Activity and Cytotoxicity of the Ethanol Extract,Fractions and Eight Compounds Isolated from Eriosema robustum (Fabaceae). BMC Complement Altern Med. 2013;13:1-9.

24. Lantzouraki DZ, Sinanoglou VJ, Zoumpoulakis P, et al. Comparison of the Antioxidant and Antiradical Activity of Pomegranate (Punica Granatum L.) by Ultrasound-Assisted and Classical Extraction. Analytical Letters. 2006;49(7):969-978.

25. Sasikala V, Saravana S, Parimelazhagan T. Evaluation of Antioxidant Potential of Different Parts of Wild Edible Plant Passiflora foetida L. Journal of Applied Pharmaceutical Science. 2011;1(4):89-96.

26. Qusti SY, Abo-khatwa AN, Lahwa M a Bin. Screening of Antioxidant Activity and Phenolic Content of Selected Food Items Cited in the Holly Quran. EJBS. 2010;2(1):40-51.

27. Sakunpak A, Pathompak P, Charoonratana T, et al. The Influence of Six Thai Edible Plants on Anti-oxidant Activities and Cholesterol Esterase Inhibition. Thai J Pharm Sci. 2016;40(26745):80-83.

28. Azlim Almey AA, Ahmed Jalal Khan C, Syed Zahir I, et al. Total Phenolic Content and Primary Antioxidant Activity of Methanolic and Ethanolic Extracts of Aromatic Plants' Leaves. Int Food Res J. 2010;17(4):1077-1083.

29. Daduang J, Vichitphan S, Daduang S, et al. High Phenolics and Antioxidants of Some Tropical Vegetables Related to Antibacterial and Anticancer Activities. African Journal of Pharmacy and Pharmacology. 2011;5(5):608-615.

30. Asir PJ, Priyanga S, Hemmalakshmi S, et al. In Vitro Free Radical scavenging Activity and Secondary Metabolites in Passiflora foetida L. Asian J Pharm Res Heal Care. 2014;6(2):3-11.

31. Subedi L, Timalsena S, Duwadi P, et al. Antioxidant Activity and Phenol and Flavonoid Contents of Eight Medicinal Plants from Western Nepal. $J$ Tradit Chinese Med. 2014;34(5):584-590.

32. Tang ELH, Rajarajeswaran J, Fung SY, et al. Antioxidant Activity of Coriandrum sativum and Protection Against DNA Damage and Cancer Cell Migration. BMC Complement Altern Med. 2013;13(347):1-13.

33. Ranković BR, Kosanić MM, Stanojković TP. Antioxidant, Antimicrobial and Anticancer Activity of the Lichens Cladonia furcata, Lecanora atra and Lecanora muralis. BMC Complement Altern Med. 2011;11(97):1-8.

34. Abu Bakar MF, Abdul Karim F, Suleiman M, et al. Phytochemical Constituents, Antioxidant and Antiproliferative Properties of a Liverwort, Lepidozia borneensis Stephani From Mount Kinabalu, Sabah, Malaysia. Evid Based Complement Alternat Med. 2015;2015:936215.

35. Dahham SS, Tabana YM, Iqbal MA, et al. The Anticancer, Antioxidant and Antimicrobial Properties of the Sesquiterpene $\beta$-Caryophyllene from the Essential Oil of Aquilaria crassna. Molecules. 2015;20(7):1180811829.

36. Yong YK, Tan JJ, Teh SS, et al. Clinacanthus nutans Extracts Are Antioxidant with Antiproliferative Effect on Cultured Human Cancer Cell Lines. Evidence-Based Complementary and Alternative Medicine. 2013:1-8

37. Varsha G, Uma Maheswari B, Ramasamy M, et al. Effect Of Ethanolic Extract Of Calophyllum inophyllum Leaves On Oxidative Stress Complications In Mouse Model. Asian Journal of Pharmaceutical and Clinical Research. 2013;9(3):250-252.

38. Bayoumi AE. Cytotoxic Evaluation of Certain Insect Growth Regulators and Insect Sex Pheromones in CHO-K1 Cells. J Egypt Soc Toxicol. $2003 ; 38: 39-47$.

39. Paulraj JA, Subharamanian H, Suriyamoorthy P, et al. Phytochemical Screening, GC-MS Analysis and Enzyme Inhibitory Activity of Passiflora foetida L. Indo American Journal of Pharmeceutical Research. 2014;4(8):3526-3234 
40. Ravichandiran V, Hema M, Adline Princy S. Inhibitors from Melia dubia Against SdiA Mediated Quorum Sensing of Uropathogenic E. coli. Int J Pharm Pharm Sci. 2015;7(1):161-166.

41. Loizzo MR, Bonesi M, Passalacqua NG, et al. Antiproliferative Activities on Renal, Prostate and Melanoma Cancer Cell Lines of Sarcopoterium spinosum Aerial Parts and Its Major Constituent Tormentic Acid. Anticancer Agents Med Chem. 2013;13(5):768-776.

42. Abay G, Altun M, Koldas S, et al. Determination of Antiproliferative Activities of Volatile Contents and HPLC Profiles of Dicranum scoparium (Dicranaceae, Bryophyta). Comb Chem High Throughput Screen. 2017;18(5):1-12.

43. Kumari M, Ghosh P, Thakur IS. Landfill Leachate Treatment Using Bacto-algal Co-culture: An Integrated Approach Using Chemical Analyses and Toxicological Assessment. Ecotoxicol Environ Saf. 2016;128:44-51.

44. Houghton PJ, Raman A. Laboratory Handbook for the Fractionation of Natural Extracts. Chapman \& Hall, . 1998. p. 66-110.

45. Malek SNA, Shin SK, Wahab NA, et al. Cytotoxic Components of Pereskia bleo (Kunth) DC. (Cactaceae) Leaves. Molecules. 2009;14(5):1713-1724.

46. Su Z, Huang H, Li J, et al. Chemical Composition and Cytotoxic Activities of Petroleum Ether Fruit Extract of Fruits of Brucea javanica (Simarubaceae). Trop J Pharm Res. 2013;12(5):735-742.
47. Easwari DV, Suresh SN, Kumar SR. Studies on Phytochemical Composition and Anticancer Potential of Methanolic Leaf Extract of Tecomella Undulata. J Pharm Biol Res. 2014;2(2):148-152.

48. López-Angulo G, Montes-Avila J, Díaz-Camacho SP, et al. Bioactive Components and Antimutagenic and Antioxidant Activities of Two Echeveria DC. Species. Industrial Crops and Products. 2016;85:38-48.

49. Witter AE. The Quantitative Determination of Butylated Hydroxytoluene in Chewing Gum Using GC-MS. Journal of Chemical Education. 2005;82(10):1538-1541.

50. Yang Z, Wu X, Yang G, et al. Antioxidant and Antibacterial Activities of Camptotheca acuminate D. Seed Oil. African J Microbiol Res. 2011;5(32):5854-5862.

51. Hamid AA, Oguntoye SO, Negi AS, et al. Chemical Constituents, Antibacterial, Antifungal and Antioxidant Activities of the Aerial Parts of Cnidoscolus aconitifolius. Ife Journal of Science. 2016;18(2):561571

52. Anjum S, Gani A, Ahmad M, et al. Antioxidant and Antiproliferative Activity of Walnut Extract (Juglans regia L.) Processed by Different Methods and Identification of Compounds Using GC/MS and LC/MS Technique. Journal of Food Processing and Preservation. 2016;41(1):1- 